\title{
20. ORGANIC GEOCHEMISTRY OF DSDP LEG 47A, SITE 397 EASTERN NORTH ATLANTIC: ORGANIC PETROGRAPHY AND EXTRACTABLE HYDROCARBONS
}

\author{
C. Cornford, J. Rullkötter, and D. Welte, Erdöl und Organische Geochemie, Kernforschungsanlage Jülich \\ $\mathrm{GmbH}, 517$ Jülich, West Germany
}

\begin{abstract}
The quantity, type, and maturity of the organic matter were determined for 45 samples of continental rise sediments from the Neogene and Lower Cretaceous at DSDP Site 397, eastern North Atlantic. Kerogen concentrates were described by microscopy, and vitrinite reflectance values were determined ( 33 samples). The hydrocarbons in lipid extracts were analyzed by gas-chromatography (GC) and combined gas chromatography-mass spectrometry (GCMS) (12 samples).

Allochthonous lower Miocene mudstones proved the most organic rich: both $n$-alkane distributions and kerogen microscopy indicated a mixed aquatic and terrestrial organic content. A dominance of phytane over pristane suggests a reducing environment of accumulation. These allochthonous-reduced sediments, slumping from the shelf edge to the continental rise, provide evidence for an oxygen-minimum layer during the Miocene in the Atlantic.

The overlying organically lean autochthonous hemipelagic oozes and chalks contain predominantly terrestrial organic matter, a paradox which is discussed. The underlying Lower Cretaceous mudstones yield $n$-alkanes and kerogens typical of higher plants.

Vitrinite reflectance and carbon preference index indicated that the section is immature, the trend from the former giving mean reflectance values of 0.45 per cent at 1450 meters.

The GC-MS analysis of polycyclic hydrocarbons identified various steranes and triterpanes, as well as important amounts of their unsaturated analogs even under a sedimentary overburden of 1450 meters. An unusual $\mathrm{C}_{28}$ triterpane was found as a dominant component in one sample.
\end{abstract}

\section{INTRODUCTION}

Site 397 (DSDP Leg 47A) was drilled in the eastern North Atlantic, $110 \mathrm{~km}$ off Cape Bojador and south of the Canary Islands. The hole was drilled at the continental rise, in an area where canyons dissect the continental shelf edge. Sediments from Tertiary and Lower Cretaceous (Hauterivian) age were separated by a $\sim$ 100 m.y. unconformity. Sediments from the site were divided into five lithostratigraphic units (Site Report, this volume); lithostratigraphic Unit 4 was subdivided into five lithofacies (F1 to F5). These units are discussed at length in the Site Report (this volume).

The majority of the 45 samples, collected from split cores using metal sampling tools, were stored frozen in "Teflon" sealed, aluminum containers until ready for laboratory processing. Some samples were taken from sediments extruded on deck by gas expanding in the plastic core liners. These were wrapped in aluminum foil and frozen. In both cases, great care was taken to remove sediment possibly contaminated during drilling or on-deck handling.

\section{MICROSCOPY}

Before burial affects the mineralogy of sedimentary rocks, the organic matter undergoes large-scale changes in both chemical and physical properties. One well-documented and relatively easily measured change is that of the increase in reflectivity of the small dispersed vitrinite-huminite ${ }^{1}$ particles present in many rocks (Raynaud and Robert, 1976).

The types of organic particles present in a sediment can also be discerned with the aid of a microscope. In its simplest form, a distinction can be made between the generally amorphous fluorescent algal or planktonic remains of aquatic origin, and non-fluorescing and structured particles such as vitrinite and inertinite of higher plant (terrestrial) origin (Stach et al., 1975). Higher plants also produce structured fluorescing tissues such as spores, cuticle, and pollen.

'The term vitrinite used in bituminous coal terminology is synonymous with the term huminite used for brown coals or lignites; the boundary is about 0.5 per cent oil reflectance (Stach et al., 1975). 


\section{Experimental}

Thirty-three samples were partially demineralized with $\mathrm{HCI}$ and the residues centifuged in a $\mathrm{kI} / \mathrm{CDI}$ solution (density 1.95). The floating fraction, termed a kerogen concentrate, was trapped on a filter, dried, and embedded in "Araldite." The "Araldite" block was ground to expose the organic particles, and polished. A Zeiss Standard Universal reflected light microscope, with a MPM 01 photometer was equipped with a $40 \times$ oil immersion objective to give an effective measuring aperture of $5 \mu \mathrm{m}$. Reflectance measurements were made using unpolarized light of $546 \mu \mathrm{m}$ (green) wavelength. The photometer output was accessed directly to a PDP-11 computer.

The measuring procedure for obtaining a mean vitrinite reflectance was as follows:

1) For each sample, measurements on 100 random particles were made to assess the range of reflectance present. A total reflectance histogram (reflectogram) and a vitrinite-only reflectogram were generated as computer output, and the vitrinite area confirmed by re-examination of the polished block.

2) Using the knowledge gained above, about 50 reflectance measurements were made on well-polished typical vitrinite. An arithmetic mean was calculated.

From observation of the kerogen concentrate in transmitted and reflected light, a semi-quantitative estimate of the "type of kerogen" was made using designations such as vitrinite, inertinite, and liptinite (Stach et al., 1975). Using ultra-violet excitation, the fluorescing liptinite macerals were identified and further subdivided (where identifiable) into spores, pollen, cuticle, algae, and amorphous matter; the amorphous matter generally was ascribed to an algal, bacterial, or planktonic origin (Teichmüller and Wolf, 1977).

\section{Description and Evaluation of Results}

Reflectance: Tables 1 and 2 give details of the samples analyzed by microscopy, the mean vitrinite reflectance values, and a brief description of the types of organic matter present in the kerogen concentrates. Figure 1 shows the plots of mean vitrinite reflectance against depth, the approximate downhole temperatures $\left(42^{\circ} / \mathrm{km}\right.$ gradient $+4^{\circ} \mathrm{C}$ at sea floor), stratigraphy, and the approximate age of the sediments.

The mean vitrinite reflectance trend with depth (Figure 1) is the end result of a number of assumptions and approximations. Firstly, it is necessary to identify the vitrinite-huminite particles among the many others present in these sediments. An example of this is given in Figure 2, which shows an attempt to differentiate between three types of "low gray" reflecting particles. Bituminite or humic matter, typically blobs of very low reflectance (horizontally ruled), and vitrinite-huminite, higher-reflecting more angular and structured particles (stippled), are distinguished from those particles showing no characteristic features (blank). Inevitably the majority of particles fall in the last category. The histograms of Figure 3 are composed only of reflectance measurements made on particles identified with rea-

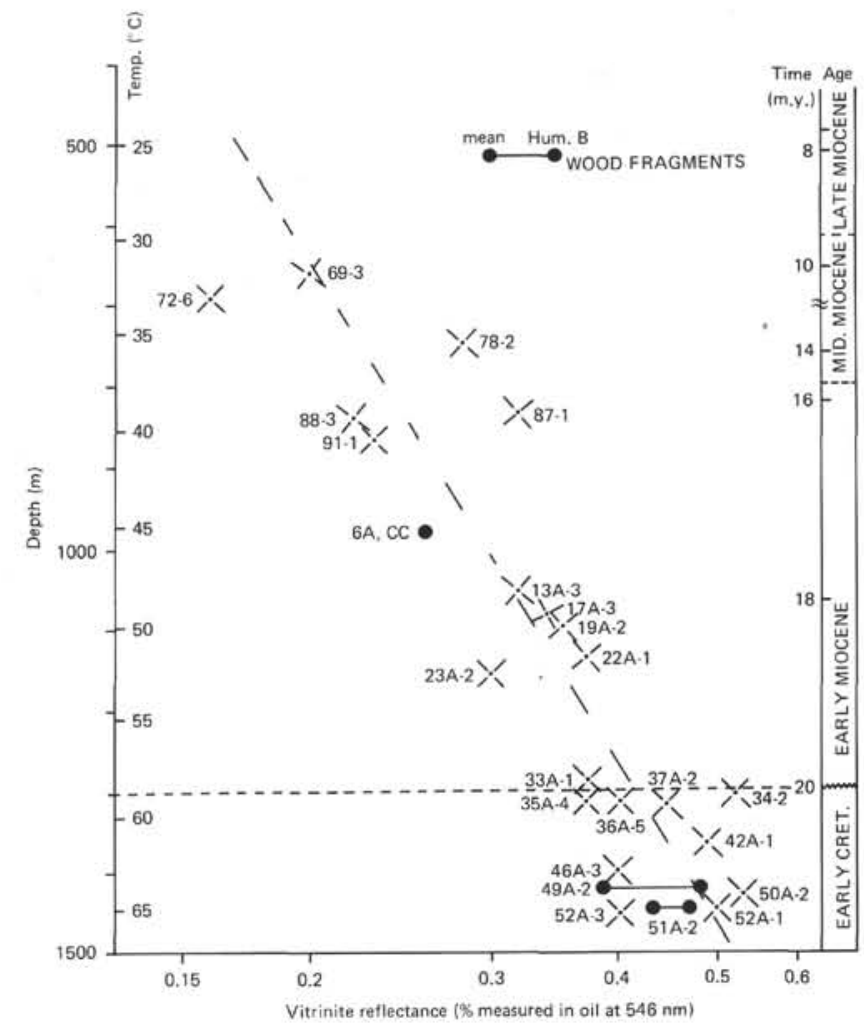

Figure 1. Mean vitrinite reflectance plotted as a function of depth for DSDP Site 397. Age and downhole temperature also plotted on vertical axis.

sonable confidence as huminite-vitrinite. Identification became easier as more mature kerogens were encountered towards the bottom of the hole.

Above the Miocene-Cretaceous unconformity at 1300 meters the vitrinite reflectograms generally show unimodal distributions (Figure 3 ). The scatter in mean values above 1000 meters (Figure 1) is to be expected since, as discussed above, particle identification at such low maturity levels is difficult. Immediately below the unconformity scatter is seen again (Figure 1), which could be due to oxidation affects associated with the unconformity. Well below the unconformity, bimodal distributions of vitrinite reflectance values are seen (Figures 2 and $3 a$ ). If the higher peak ( 0.50 to 0.65$)$ of this bimodal distribution is accepted as valid, this indicates that the Cretaceous sediments have been subjected to significantly higher levels of maturation than the Miocene above the unconformity (e.g., present-day burial $+700 \mathrm{~m}=2.0 \mathrm{~km}$ would not be unreasonable). If the lower reflectance maxima are accepted, then a reflectance level below the unconformity of 0.3 to 0.35 is indicated. Such a level of maturity is low for the measured downhole temperature of $65^{\circ} \mathrm{C}$ (Demaison, 1975) although the time of exposure to this temperature is short (high Neogene sedimentation rate). It is also in poor agreement with the trend established above the unconformity.

From consideration of the factors given above, the solution favored is to ignore the bimodal distribution 
TABLE 1

Organic Petrographic Results From the Tertiary Samples, Lithostratigraphic Units 1 to 4, DSDP Site 397

\begin{tabular}{|c|c|c|c|c|c|c|c|c|c|}
\hline \multirow{2}{*}{$\begin{array}{c}\text { Sample } \\
(\text { Interval in } \mathrm{cm})^{\mathrm{a}}\end{array}$} & \multirow{2}{*}{$\begin{array}{l}\text { Depth } \\
\text { (m) }\end{array}$} & \multirow[b]{2}{*}{ Lithology } & \multirow{2}{*}{$\begin{array}{c}\mathrm{C}_{\text {org. }} \\
(\%)\end{array}$} & \multirow{2}{*}{$\begin{array}{c}\text { Density } \\
\text { Concen- } \\
\text { trate } \\
\text { Yield } \\
(\%)\end{array}$} & \multirow{2}{*}{$\begin{array}{c}\text { Mean } \\
\text { Vitrinite } \\
\text { Reflec- } \\
\text { tance } \\
(\%, \text { oil })\end{array}$} & \multicolumn{4}{|r|}{ Maceral Analysis } \\
\hline & & & & & & $\mathrm{V}(\%)$ & I $(\%)$ & $\mathrm{L}(\%)$ & Comments on liptinites \\
\hline \multicolumn{10}{|l|}{ Hole 397} \\
\hline $\begin{array}{l}10-4,121-132 \\
12-5 \text { (Bot) }^{\mathrm{a}} \\
20-3 \text { (Top) }^{\mathrm{a}} \\
22-3 \text { (Top) } \\
44-3,89-98 \\
69-3,58-60 \\
72-6 \text { (Top) } \\
78-2,73-87 \\
87-1,111-113 \\
88-3,64-70 \\
91-1,118-130\end{array}$ & $\begin{array}{r}91 \\
142 \\
185 \\
204 \\
413 \\
660 \\
693 \\
744 \\
828 \\
840 \\
866\end{array}$ & $\begin{array}{l}\text { F3 } \\
\text { F3 } \\
\text { F2 } \\
\text { F2 } \\
\text { F4 } \\
\text { F4 }\end{array}$ & $\begin{array}{l}0.72 \\
0.66 \\
0.30 \\
0.53 \\
0.17 \\
0.45 \\
2.31 \\
0.26 \\
1.43 \\
1.03 \\
0.84\end{array}$ & $\begin{array}{l}0.01 \\
0.03 \\
0.01 \\
0.01 \\
0.10 \\
0.04 \\
0.13 \\
0.02 \\
0.14 \\
0.03 \\
0.02\end{array}$ & $\begin{array}{l}\text { n.d. } \\
\text { n.d. } \\
\text { n.d. } \\
\text { n.d. } \\
\text { n.d. } \\
0.20 \\
0.16 \\
0.28 \\
0.32 \\
0.22 \\
0.23\end{array}$ & $\begin{array}{r}50 \\
30 \\
5 \\
50 \\
50 \\
50 \\
50 \\
40 \\
90 \\
60 \\
60\end{array}$ & $\begin{array}{l}30 \\
50 \\
70 \\
20 \\
20 \\
30 \\
20 \\
40 \\
10 \\
20 \\
10\end{array}$ & $\begin{array}{r}20 \\
20 \\
1 \\
30 \\
30 \\
20 \\
30 \\
20 \\
<1 \\
20 \\
30\end{array}$ & $\begin{array}{l}\text { Algae, pollen cuticle } \\
\text { Pollen, fluorescing background } \\
\text { Pollen, fluorescing particles } \\
\text { Pollen, amorphous fluoresc. backgr. } \\
\text { Pollen, cuticle } \\
\text { '"Bituminite" single cells, fl. filaments } \\
\text { "Bituminite" single cells, cuticle, pollen } \\
\text { Amorphous liptinite } \\
\text { "Bituminite" and cellular fragment } \\
\text { Cuticle, particulate fl., + fl. background } \\
\text { Fluorescing background + cuticle }\end{array}$ \\
\hline \multicolumn{10}{|l|}{ Hole 397A } \\
\hline $\begin{array}{l}6, \mathrm{CC} \\
13-3,37-45 \\
16-5 \text { (Bot) } \\
17-3,47-49 \\
19-2,100-110 \\
22-1,59-61 \\
23-2,64-69 \\
31-1,15-18 \\
33-1,100-111\end{array}$ & $\begin{array}{r}982 \\
1054 \\
1076 \\
1082 \\
1100 \\
1136 \\
1157 \\
1269 \\
1288\end{array}$ & $\begin{array}{c}\text { wood } \\
\text { F3 } \\
\text { F4 } \\
\text { F4 } \\
\text { F5 } \\
\text { F4 } \\
\text { F5 } \\
\text { F3 }\end{array}$ & $\begin{array}{l}2 . \overline{76} \\
\text { n.d. } \\
2.03 \\
0.35 \\
\text { n.d. } \\
0.71 \\
1.79 \\
2.66\end{array}$ & $\begin{array}{l}-\bar{c} \\
0.07 \\
\text { n.d. } \\
0.10 \\
0.01 \\
\text { n.d. } \\
0.01 \\
0.0\end{array}$ & $\begin{array}{l}0.26 \\
0.32 \\
\text { n.d. } \\
0.34 \\
0.35 \\
0.37 \\
0.30 \\
0.30\end{array}$ & $\begin{array}{l}90 \\
60 \\
40 \\
95 \\
30 \\
80 \\
50 \\
50\end{array}$ & $\begin{array}{l}10 \\
30 \\
40 \\
<1 \\
20 \\
10 \\
30 \\
10 \\
<1\end{array}$ & $\begin{array}{r}- \\
10 \\
20 \\
5 \\
50 \\
10 \\
20 \\
40 \\
60\end{array}$ & $\begin{array}{l}\text { Cell structured wood } \\
\text { Fluorescing particles, pollen } \\
\text { Algal laths + fluorescing particles } \\
\text { As above } \\
\text { Fluorescing particles, pollen } \\
\text { Fluorescing part. and background } \\
\text { Particulate fluorescing matter } \\
\text { Particulate + filamentous fluorescing } \\
\quad \text { matter } \\
\text { Cuticle, fluorescing particles }\end{array}$ \\
\hline
\end{tabular}

${ }^{\mathrm{a}}$ Intervals (Bot) and (Top) represent core extruded from the bottom and top of the section, respectively.

TABLE 2

Organic Petrographic Results From the Cretaceous Samples, DSDP Hole 397A

\begin{tabular}{|c|c|c|c|c|c|c|c|c|c|c|}
\hline \multirow{2}{*}{$\begin{array}{c}\text { Sample } \\
\text { (Interval in } \mathrm{cm} \text { ) }\end{array}$} & \multirow{2}{*}{$\begin{array}{l}\text { Depth } \\
\text { (m) }\end{array}$} & \multirow[b]{2}{*}{ Age } & \multirow[b]{2}{*}{ Lithology } & \multirow{2}{*}{$\begin{array}{l}\text { C-org } \\
(\%)\end{array}$} & \multirow{2}{*}{$\begin{array}{c}\text { Density } \\
\text { Concen- } \\
\text { trate } \\
(\%)\end{array}$} & \multirow{2}{*}{$\begin{array}{c}\text { Mean } \\
\text { Vitrinite } \\
\text { Reflec- } \\
\text { tance } \\
\text { (\% oil) }\end{array}$} & \multicolumn{4}{|c|}{ Maceral Analysis } \\
\hline & & & & & & & $\mathrm{V}(\%)$ & I $(\%)$ & $\mathrm{L}(\%)$ & Comments on Liptinites \\
\hline $34-2,67-69$ & 1299 & Lower Cret. & Laminated mudstone & 0.42 & 0.20 & 0.52 & 90 & 1 & 10 & Pollen, cuiticle \\
\hline $35-4,24-42$ & 1310 & Lower Cret. & Laminated mudstone & 0.60 & 0.10 & 0.37 & 90 & 5 & 5 & High-rank cuticle (Ro $0.5 \%$ ) \\
\hline $36-5,22-25$ & 1315 & Lower Cret. & Laminated mudstone & 0.90 & 0.30 & 0.40 & 90 & 2 & 8 & Derived spores \\
\hline $37-2,83-86$ & 1318 & Lower Cret. & Laminated mudstone & 0.64 & 0.40 & 0.44 & 90 & 4 & 10 & Fl. particles \\
\hline $40-1,118-129$ & 1345 & Lower Cret. & Laminated mudstone & 0.46 & 0.09 & - & 90 & 1 & 10 & Fl. particles \\
\hline $42-1,27-30$ & 1363 & Lower Cret. & Laminated mudstone & n.d. & 0.15 & 0.49 & 95 & i & 5 & Globular particles \\
\hline $46-3,35-46$ & 1396 & Lower Cret. & Laminated mudstone & 0.47 & 0.04 & 0.40 & 90 & 2 & 2 & Few spores \\
\hline $49-2,54$ & 1421 & Lower Cret. & Wood & - & - & 0.38 & Cell & lar str & cture & \\
\hline $50-2,29-31$ & 1433 & Lower Cret. & Laminated mudstone & n.d. & 0.30 & 0.53 & 95 & 2 & 3 & Cuticle, spores \\
\hline $51-2,49$ & 1441 & Lower Cret. & Wood & - & - & 0.43 & Cellu & ar stru & ure & \\
\hline $52-1,77-86$ & 1449 & Lower Cret. & Laminated mudstone & 1.06 & 0.26 & 0.50 & 90 & 2 & 8 & Fl. particles \\
\hline $52-2,84-86$ & 1450 & Lower Cret. & Laminated mudstone & n.d. & n.d. & 0.40 & 95 & 1 & 15 & Globular fl. particles and laths \\
\hline $52-3,17-33$ & 1453 & Lower Cret. & Laminated mudstone & 1.49 & 0.50 & 0.40 & 90 & 4 & 6 & Spores \\
\hline
\end{tabular}

and calculate an arithmetic mean of the values in the total spread of both peaks where they appear. These values are plotted in Figure 1, and indicate no break in maturity across the unconformity at 1300 meters.

The dashed trend line resulting from this latter interpretation is confirmed by more precise reflectance data from three macroscopic wood fragments obtained from Miocene Sample 397A-6-3, CC and Cretaceous Samples 397A 49-2, $57 \mathrm{~cm}$ and 397A 51-2, $49 \mathrm{~cm}$. Cell structure can be seen in these samples and the reflectance measurements made on the higher reflecting ma- terial of the humotelinite subgroup (Stach et al., 1975). Since this maceral subgroup forms a continuous transitional maturational series with vitrinite, measurement of this higher reflecting huminite is preferred as a rank index. Both the mean reflectance data points for the humotelinite component of the three wood fragments, and the means of the total histograms are shown in Figure 1 as solid points.

Kerogen type: The type of the organic matter, briefly described in Table 1 for the Miocene and Table 2 for the Cretaceous, must be interpreted in the light of 

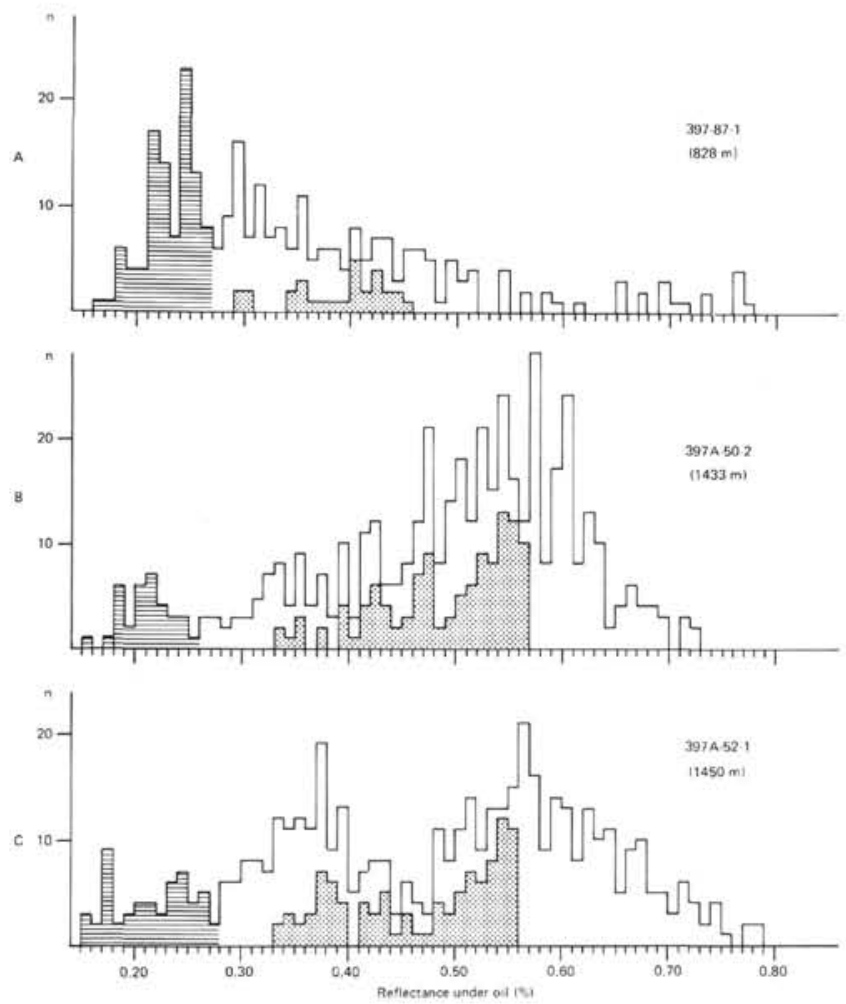

Figure 2. Total reflectance histograms of 500 points showing areas containing "bituminite?" or humic matter (ruled), and well-characterizable vitrinite/ huminite (stippled). The remaining particles measured showed no characteristic form. Vertical scale, $\mathrm{n}=$ number of particles/interval.

the very low efficiency of the particle concentration process, i.e., never $>60$ per cent and typically $<10$ per cent of the organic carbon content (Tables 1 and 2, density concentrate yield columns). The particles seen under the microscope represent only a part of the total organic matter in the rocks.

In both Tertiary and Mesozoic samples, the isolated particles are predominantly of higher plant origin: vitrinite (of humic origin), fusinite (oxidized or carbonized woody matter), leaf cuticle, spores, and pollen. Amorphous fluorescing matter, algal filaments, or cells are present only as relatively minor components in the hemipelagic sediments of Units 1,2 , and 3 to 690 meters.

Unit 4, with its five relatively distinct lithofacies (Site Report, this volume; Table 1) shows a wider variety of maceral types. It can be seen from Table 1 that, of the Unit 4 lithofacies analyzed, there is a tendency towards greater algal contributions to lithofacies Subunit F4a, which forms the "shell hash" slumped matrix of this allochthonous unit. In contrast, the turbidite lithofacies Sub-units F2 (coarse) and F3 (fine) have more higher plant particulate fluorescing components, such as pollen and cuticle. Facies F2 also contains macroscopic wood fragments (e.g., Sample 397A6-3, CC). The distinction between F4a, and F2 and F3, is not clear-cut, which is to be expected since lithofacies Sub-unit F4a contains clasts of F2 and F3.

The kerogen particles isolated from the Hauterivian (Lower Cretaceous) below the unconformity are predominantly of higher plant origin, vitrinite being the major maceral (Table 2). Spores were a minor but consistent component. Some of these spores showed a very low intensity, anomalously red fluorescence, and a higher reflectance than expected for the maturity level of the vitrinite. This may be due either to the presence of recycled spores derived from eroded more mature sediments or to oxidation and weathering during distal transport. Only minor amounts of possibly recycled (higher reflectance) vitrinites could be found (Figure 2A).

\section{EXTRACTION OF HYDROCARBONS}

Extraction was carried out on a smaller number of samples. Twelve samples were selected to be free of lipid-soluble organic contamination. A volcaniclastic sand (Section 397-84-3 at $801 \mathrm{~m}$ ) was extracted as a "blank" to monitor the level of contamination during sampling and in the laboratory procedures.

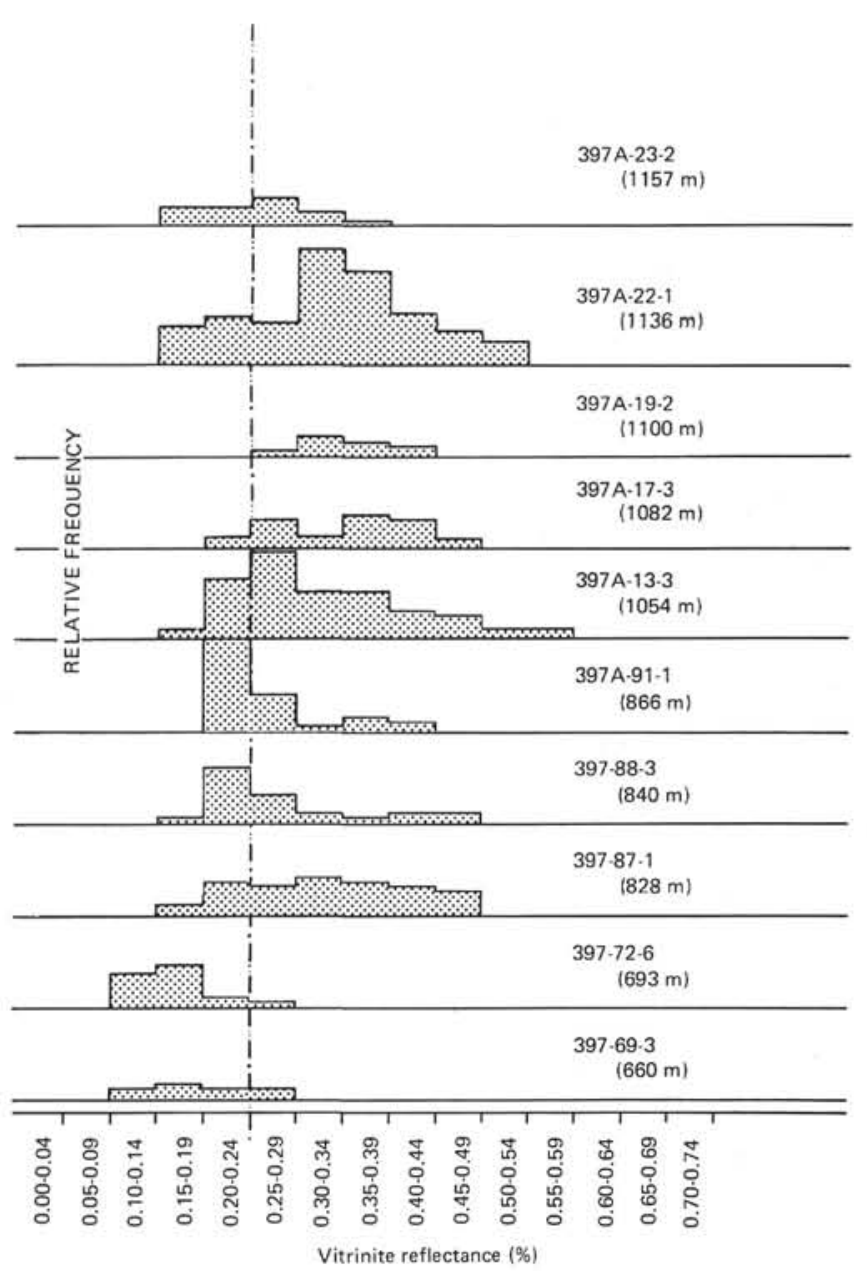

Figure 3a. Vitrinite reflectance histograms for DSDP Site 397. 


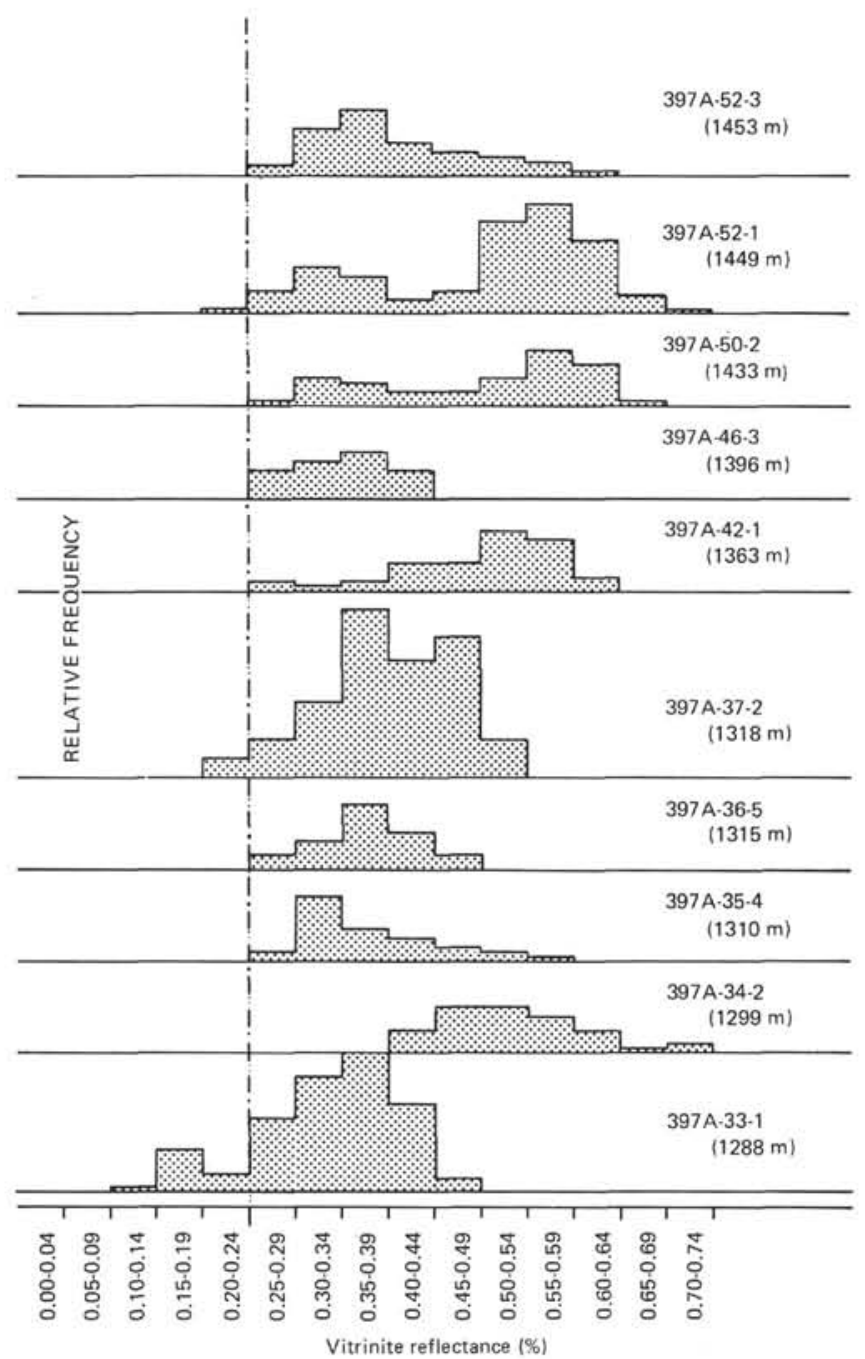

Figure 3b. Vitrinite reflectance histograms for DSDP Site 397.

\section{Experimental}

The frozen samples were thawed, dryed at $50^{\circ} \mathrm{C}$ for 12 hours, and ground. The ground sediment was extracted in a soxhlet apparatus for 20 hours using an azeotropic mixture of chloroform-menthanol, to give (after removal of solvent) a total extract. The total extract was fractionated on a silica gel-alumina column; for small total extract weights, thin-layer silica gel plates were used. Three fractions were collected (Table 3 ), eluted with cyclohexane, dichloromethane, and methanol. Solvents used were either analytical grade or were redistilled prior to use.

The cyclohexane fraction which generally contains non-aromatic hydrocarbons was further analyzed using packed column and glass capillary column gas chromatography (GC) and, where quantities allowed, capillary gas chromatography-mass spectrometry (GC-MS).

Packed column GC work was performed using a Hewlett Packard 5711 gas chromatograph equipped with a $10 \mathrm{ft} \times 2 \mathrm{~mm}$ (i.d.) glass column packed with 5 per cent eutectic mixture of alkaline nitrates on Chromosorb GAW (60/80 mesh). Nitrogen was used as carrier gas (flow rate $15 \mathrm{ml} / \mathrm{min}$ ); the temperature was programmed from $100^{\circ} \mathrm{C}$ to $280^{\circ} \mathrm{C}$ at $8^{\circ} \mathrm{C} / \mathrm{min}$.

Capillary gas chromatograms were obtained on a 20 $\mathrm{m} \times 0.3 \mathrm{~mm}$ (i.d.) glass capillary coated with SE 52 which was fitted to a Siemens 420 gas chromatograph. Hydrogen was used as carrier gas $(3 \mathrm{ml} / \mathrm{min})$; the temperature was programmed from $75^{\circ} \mathrm{C}$ to $240^{\circ} \mathrm{C}$ at $3^{\circ} \mathrm{C} / \mathrm{min}$.

Mass spectra were recorded on a MS 3074 mass spectrometer (AEI, Manchester) which was coupled directly to a PYE 104 gas chromatograph. Samples were injected splitless on a $20 \mathrm{~m} \times 0.3 \mathrm{~mm}$ (i.d.) glass capillary column coated with OV-1, programmed from 100 to $260^{\circ} \mathrm{C}$ at $3{ }^{\circ} \mathrm{C}$ per minute (carrier gas: helium, $3 \mathrm{ml} /$ $\mathrm{min}$ ). The ionization voltage was $70 \mathrm{eV}$, the mass spectrometer scanning continuously at $1 \mathrm{sec}$ per decade (m/ e 650 to 30 ). The data were acquired and processed using an AEI DS-50 data system. Single ion plots and mass spectra were used to identify the cyclic hydrocarbons present in the samples.

\section{Description and Evaluation of Results}

Extract quantity and $n$-alkane distributions: As can be seen from Table 3, the quantity of total extract is more a function of the sediment type (and organic carbon content) than depth. The percentage of cyclohexane fraction in the total extract was low, typically $<5$ per cent (Table 3 ).

The volcanic sand from Sample 397-84-3, $75-83 \mathrm{~cm}$ was taken as a blank and gave very low levels of extract (12 ppm) A GC-MS analysis of the cyclohexane fraction of this sample showed only "noise" even when run at high sensitivity.

The packed (eutectic) column GC analysis showed that the Tertiary samples from 130 to 1241 meters contained an unresolved "hump" of naphthenic or other compounds. On top of the "hump," resolved peaks of normal, branched, and cyclic alkanes were seen. The "hump" was much less noticeable using a capillary column. Little unresolved hydrocarbon was present in the Cretaceous sample from Section 397A-52-3 at 1450 meters.

The four hemipelagic sediment samples from Hole 397 Sections 14-2 (Figure 4A), 21-3, 24-6 (Figure 4B), and $72-5$ had $n$-alkane distributions showing maxima in the $\mathrm{C}_{29}$ to $\mathrm{C}_{31}$ region with a high odd/even carbon preference ( Table 3 ). Resolved cyclic and branched molecules formed a small part of the hydrocarbons in this hemipelagic interval; pristane and phytane were only present as minor peaks.

The GC traces of lithostratigraphic Unit 4 samples (690 to $1241 \mathrm{~m}$ ) showed more complex chromatograms with many non-alkane peaks. The $n$-alkane distributions maximized in the $C_{17}$ to $C_{22}$ region for samples from Sections 397-87-2 (Figure 4C) and 397A-192 , while bimodal distributions were found for samples from Sections 23-3 and 24-4 of Hole 397A. The sample from Section 397A-28-2 showed no detectable $n$-alkanes at all. Phytane was a major peak in samples from Sections 23-3 and 24-4 of Hole 397A. Phytane always dominated over pristane. The Cretaceous sample (Sec- 

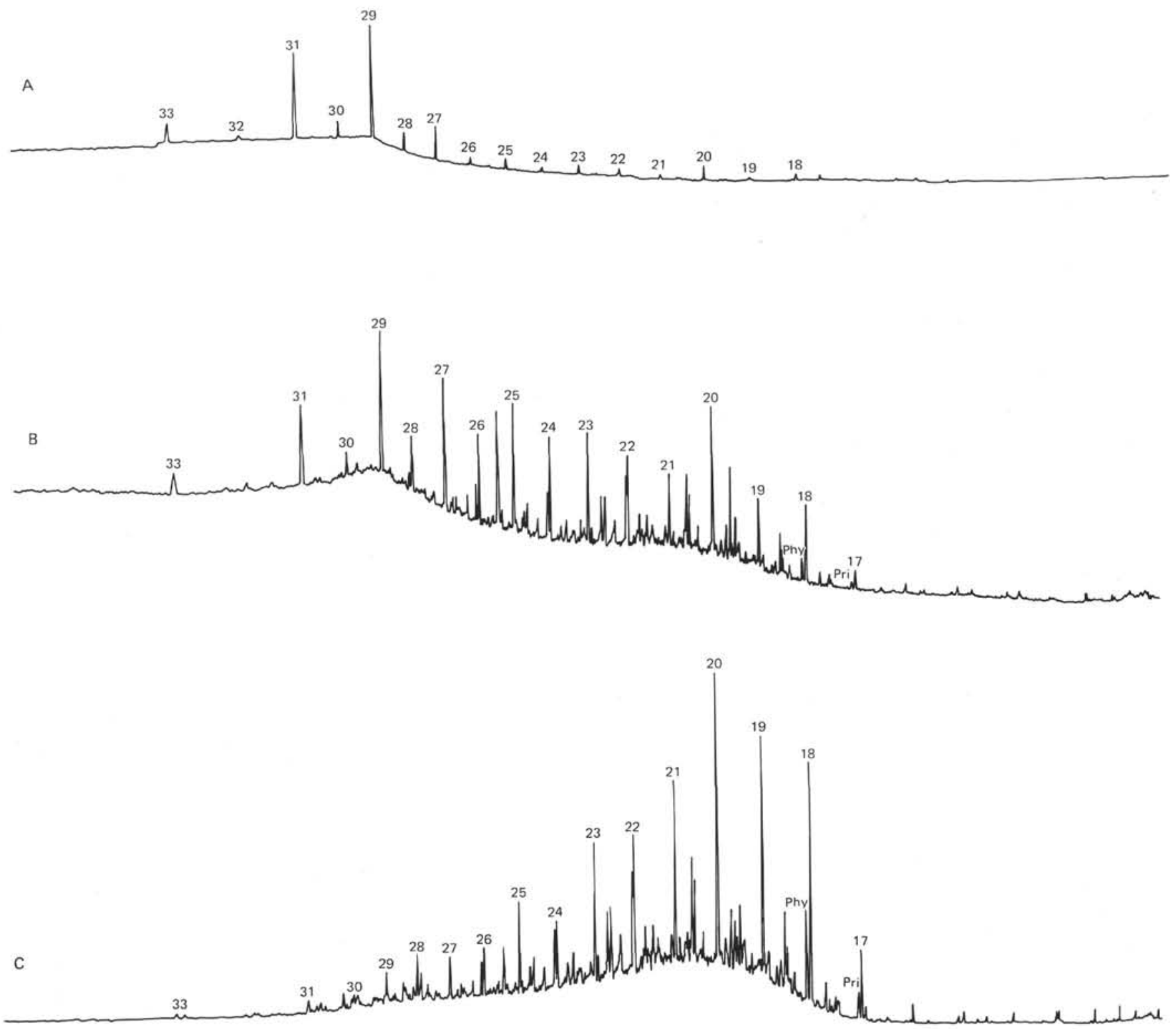

Figure 4. Capillary chromatograms of cyclohexane column fractions of extracts from (A) 397-14-2 (top), 130 meters depth, Quaternary; (B) 397-24-6 (top), 225 meters depth, Pliocene; (C) 397-87-2, 20-30 cm, 828 meters depth, Miocene, F2/F3.

tion 397A-52-3) showed $\mathrm{N}$-alkanes maximizing in the $\mathrm{C}_{25}$ to $\mathrm{C}_{29}$ region. Phytane and a minor pristane peak were present.

Carbon preference indexes (CPI) values, calculated as the peak height ratio $\mathrm{C}_{25}+\mathrm{C}_{27}+\mathrm{C}_{29}+\mathrm{C}_{31} / \mathrm{C}_{24}$ $+\mathrm{C}_{26}+\mathrm{C}_{28}+\mathrm{C}_{30}$, were in the range 1.21 to 4.42 (Table 3 ). In the Tertiary section, a decrease in CPI with increasing depth is noted, but the high value for the Cretaceous sample reverses this depth trend.

Mass spectrometric study of cyclic hydrocarbons: Mass spectrometric analyses of the aliphatic hydrocarbon fractions were carried out on five samples from lithostratigraphic Unit 4 (Sections $72-5$ and $87-2$ of Hole 397; Sections 19-2, 23-3 and 28-2 of Hole 397A) and one sample from Unit 5 (Section 397A-52-3). The dis- tribution of non-aromatic polycyclic biological marker compounds may give information about possible allochthonous terrigenous influx and conditions during sedimentation.

\section{Samples From Lithostratigraphic Unit 4 (Lower Miocene)}

A complex mixture of hydrocarbon derivatives of steroids and pentacyclic triterpenoids (Figure 5) was detected by GC-MS analysis in samples from Sections $72-5$ and $87-2$ of Hole 397 (690 and $828 \mathrm{~m}$ ), respectively), and Sections 19-2, 24-4, and 28-2 of Hole 397A $(1100,1180$, and $1241 \mathrm{~m}$, respectively).

These cyclic compounds in each case represented a major part of the cyclohexane eluted fraction obtained 
TABLE 3

Extract Weights and Column Fractions, DSDP Site 397

\begin{tabular}{|c|c|c|c|c|c|c|c|c|c|}
\hline \multirow[b]{2}{*}{$\begin{array}{c}\text { Sample } \\
\text { (Interval in } \mathrm{cm} \text { ) }\end{array}$} & \multirow[b]{2}{*}{$\begin{array}{l}\text { Depth } \\
\text { (m) }\end{array}$} & \multirow[b]{2}{*}{ Age } & \multirow[b]{2}{*}{ Sedimentology } & \multirow[b]{2}{*}{$\begin{array}{l}\text { C-org } \\
(\%)\end{array}$} & \multirow[b]{2}{*}{$\begin{array}{l}\text { Extract } \\
\text { (ppm) }\end{array}$} & \multicolumn{3}{|c|}{ Column Fractions ${ }^{\mathrm{a}}$} & \multirow{2}{*}{$\begin{array}{c}\text { C.P.I. } \\
\text { (see } \\
\text { text) }\end{array}$} \\
\hline & & & & & & $\begin{array}{l}\text { Hex. } \\
(\%)\end{array}$ & $\begin{array}{c}\text { DCM } \\
(\%)\end{array}$ & $\begin{array}{c}\mathrm{MeOH} . \\
(\%)\end{array}$ & \\
\hline \multicolumn{10}{|l|}{ Hole 397} \\
\hline $\begin{array}{l}14-2 \text { (Top) } \\
21-3 \text { (Top) } \\
24-6 \text { (Top) } \\
72-5,116-123 \\
75-2,13-25 \\
84-3,75-83 \\
87-2,20-30\end{array}$ & $\begin{array}{l}130 \\
190 \\
225 \\
690 \\
727 \\
801 \\
828\end{array}$ & $\begin{array}{l}\text { Quaternary } \\
\text { Pliocene } \\
\text { Pliocene } \\
\text { Miocene } \\
\text { Miocene } \\
\text { Miocene } \\
\text { Miocene }\end{array}$ & $\begin{array}{l}\text { Hemipelagic } \\
\text { ooze } \\
\text { F3 } \\
\text { F5 } \\
\text { volc. sand } \\
\text { F2/3 }\end{array}$ & $\begin{array}{l}0.59 \\
0.50 \\
0.34 \\
1.09 \\
0.58 \\
0.02 \\
1.94\end{array}$ & $\begin{array}{c}423 \\
489 \\
275 \\
1876 \\
61^{\mathrm{b}} \\
12^{\mathrm{b}} \\
792\end{array}$ & $\begin{array}{l}1.3 \\
6.5 \\
8.5 \\
3.9 \\
1 \\
\text { n.d. } \\
6.5\end{array}$ & $\begin{array}{c}3.8 \\
8.0 \\
8.5 \\
6.1 \\
50 \\
\text { n.d. } \\
4.6\end{array}$ & $\begin{array}{l}94.9 \\
85.6 \\
82.9 \\
90.0 \\
50 \\
\text { n.d. } \\
88.9\end{array}$ & $\begin{array}{l}2.91 \\
3.04 \\
2.45 \\
\text { n.d. } \\
2.93 \\
\text { n.d. } \\
1.21\end{array}$ \\
\hline \multicolumn{10}{|l|}{ Hole 398A } \\
\hline $\begin{array}{l}19-2,15-25 \\
23-3,85-93 \\
24-4,67-74 \\
28-2,121-133 \\
52-3,17-33\end{array}$ & $\begin{array}{l}1100 \\
1160 \\
1180 \\
1241 \\
1450\end{array}$ & $\begin{array}{l}\text { Miocene } \\
\text { Miocene } \\
\text { Miocene } \\
\text { Miocene } \\
\text { Cretaceous }\end{array}$ & $\begin{array}{l}\text { F3 } \\
\text { F5 } \\
\text { F3 } \\
\text { F2 } \\
\text { mudst. }\end{array}$ & $\begin{array}{l}4.47 \\
0.52 \\
2.02 \\
2.89 \\
0.72\end{array}$ & $\begin{array}{r}1153 \\
22^{\mathrm{b}} \\
1385 \\
1101 \\
477\end{array}$ & $\begin{array}{l}2.9 \\
1 \\
2.3 \\
3.2 \\
5.2\end{array}$ & $\begin{array}{l}7.1 \\
44.7 \\
37 \\
12.9 \\
9.8\end{array}$ & $\begin{array}{l}90.0 \\
55.3 \\
94.0 \\
83.8 \\
84.9\end{array}$ & $\begin{array}{l}1.29 \\
\text { n.d. } \\
\text { n.d. } \\
\text { n.d. } \\
4.42\end{array}$ \\
\hline
\end{tabular}

${ }^{\mathrm{a}} \mathrm{Hex}=$ hexane, $\mathrm{DCM}=$ dichloromethane, $\mathrm{MeOH}=$ methanol. Fractions given as a percentage of the material eluted from the coiumn.

${ }^{b}$ Low extract quantities required use of thin-layer chromatography to make these separations.

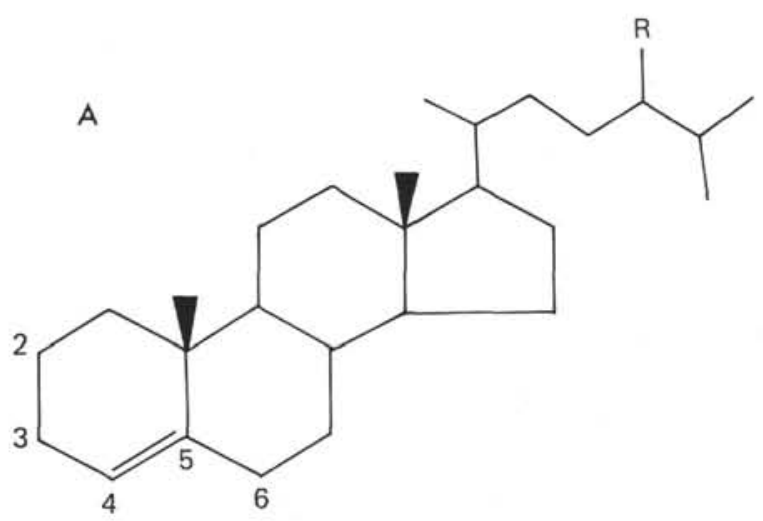

$$
\mathrm{C}_{\mathrm{n}} \mathrm{H}_{2 \mathrm{n}-8}
$$

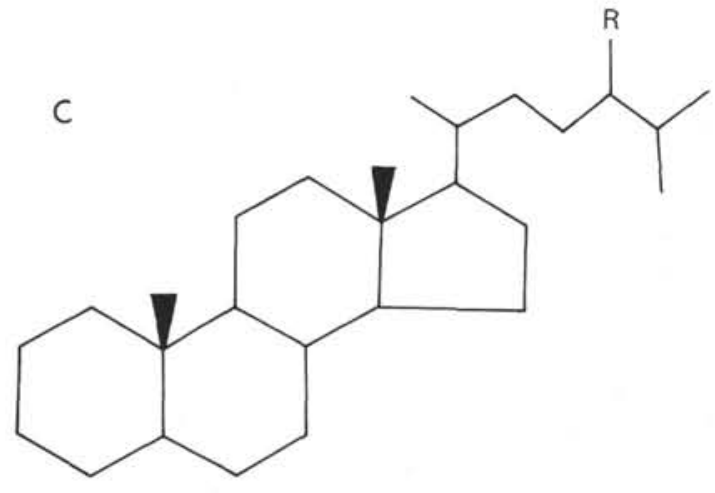

$$
\mathrm{C}_{\mathrm{n}} \mathrm{H}_{2 \mathrm{n}-6}
$$

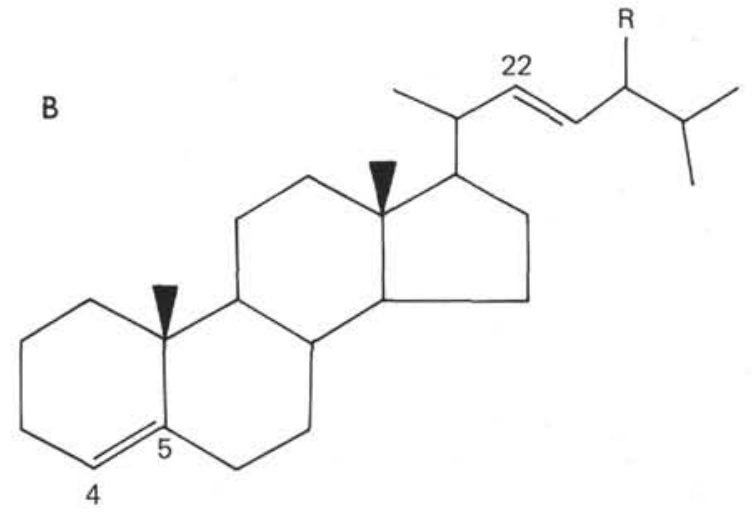

$\mathrm{C}_{\mathrm{n}} \mathrm{H}_{2 \mathrm{n}-10}$

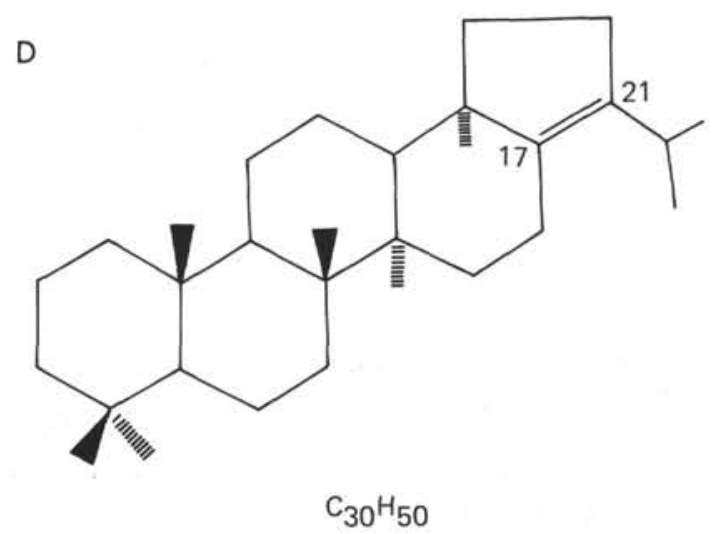

Figure 5. Structures of cyclic hydrocarbons found in samples from DSDP Site 397. 
from silica gel chromatography. The $n$-alkane content was variable, but generally decreased with increasing depth relative to the amount of branched and cyclic compounds, as indicated by the total ion current traces in Figure 6 (A to $C$ ).

Mono- $\mathrm{C}_{n} \mathrm{H}_{2 n-8}, n=27$ to 29 ) and di-unsaturated $\left(\mathrm{C}_{n} \mathrm{H}_{2 n-10}, n=28\right.$ to 29$)$ steroid hydrocarbons (Figure 7A) were main contributors to the cyclics giving nearly the same distribution pattern in all five samples. In some cases, localization of double bonds and therefore assignment of certain structures was possible by comparison with published mass spectra and from relative retention times.

For example $\Delta^{4}$-cholestene (Figure $5 \mathrm{~A}, \mathrm{R}=\mathrm{H}$; Figure $8 \mathrm{~A}$ ), and $\Delta^{5}$-cholestene were the main representatives of mono-unsaturated sterenes and were detected in nearly equal amounts. $\Delta^{2}$-cholestene was tentatively identified as a trace component only. Most of the steradienes appeared to have one double bond in the side chain, mainly in the $\Delta^{22}$-position, as indicated by mass spectral fragmentation (Wyllie and Djerassi, 1968), the other occurring in the ring moiety, most probably in the $\Delta^{4}$ (Figure 5B) or $\Delta^{5}$-position.

Some saturated steranes (Figure $5 \mathrm{C}, \mathrm{C}_{n} \mathrm{H}_{2 n-6}, n=$ 27 to 29) were found, too, but they were considerably less abundant than their unsaturated analogs. Evidence was found for the presence of rearranged sterenes $\left(\mathrm{C}_{27^{-}}\right.$ 29) which were eluted from the column well in front of the normal sterenes of equal $\mathrm{C}$-number (see mass chromatogram m/e 257, Figure 7A). Finally, the mass spectra of three isomeric saturated $\mathrm{C}_{24}$-steranes were obtained from the sample from Section 397A-28-2 (1241 m).

Triterpenes $\left(\mathrm{C}_{n} \mathrm{H}_{2 n-10}, n=27,29\right.$ to 31$)$ were present in small amounts in all samples. No structures could be assigned except for hop-(17,21)-ene (IV) which was the major $\mathrm{C}_{30}$-triterpene. The amount of fully saturated pentacyclic triterpanes was found to be low, though increasing with depth, as did the total triterpenoid hydrocarbons relative to steroid hydrocarbons. The only exception was the sample from Section 397A-28-2 $(1240 \mathrm{~m})$ which was dominated by an unusual $\mathrm{C}_{28^{-}}$ triterpane (probably two isomers, Figure $7 \mathrm{~B}$ ). The mass spectrum (Figure $8 \mathrm{~B}$ ) showed in addition to the moecular ion at $\mathrm{m} / \mathrm{e} 384 \mathrm{a}$ base peak at $\mathrm{m} / \mathrm{e} 191$ and major fragments at $\mathrm{M}^{+} 1-15$ and $\mathrm{M}^{+1} 1-29$.

Cyclic diterpenoid hydrocarbons $\left(\mathrm{C}_{n} \mathrm{H}_{2 n-8}, n=23\right.$, $\mathrm{C}_{n} \mathrm{H}_{2 n-6}, n=18,20$ to $21 ; \mathrm{C}_{n} \mathrm{H}_{2 n-4}, n=20$ to 21 could only be detected in small amounts in Section 397A-282 (1241 m).

\section{Samples From Lithostratigraphic Unit 5 (Cretaceous)}

The sample from Section 397A-52-3 (1450) showed an " $n$ "'-alkane distribution with strong odd/even predominance together with a maximum at $\mathrm{C}_{27}$ (Figure 6D) which is characteristic of terrestrial higher plant distributions. The complete lack of steroid hydrocarbons (within the detection limits of the spectrometer) was another striking difference between this and the Miocene samples. In addition to different pentacyclic triterpenes $\left(\mathrm{C}_{27}, \mathrm{C}_{29}, \mathrm{C}_{31}\right)$, only small quantities of fully saturated triterpanes $\left(\mathrm{C}_{29}-\mathrm{C}_{31}\right.$ could be detected. Cyclic diter- penoid gydrocarbons were not found. The overall content of cyclic compounds relative to $n$-alkanes and other open-chain hydrocarbons was much lower than in the Miocene samples described above.

\section{DISCUSSION AND CONCLUSIONS}

\section{Maturity}

On the basis of the vitrinite reflectance trend (Figure $1)$, the sediments are immature over the whole section, only reaching values of about 0.5 per cent $R_{o}$ at 1500 meters. This is an agreement with the downhole temperature measurements (Figure 1; and Site Report, this volume), the high values of the carbon preference index (Table 3), the low extractability relative to the organic carbon values, and the large amounts of unsaturated polycylic hydrocarbons found in the extracts. This low level of maturity is to be expected in the relatively shallow DSDP holes, although the measured geothermal gradient at this site $\left(42^{\circ} \mathrm{C} / \mathrm{km}\right)$ is high for a passive margin setting.

The vitrinite reflectance data indicate that the base of the hole at 1453 meters is just reaching the zone of the onset of appreciable hydrocarbon generation, which is generally taken as about 0.5 per cent reflectance (e.g., Dow, 1977).

The correspondence of the 0.5 per cent reflectance level with an extrapolated downhole temperature of about $65^{\circ} \mathrm{C}$ is in agreement with published data (Demaison, 1975), although it falls in the upper temperature range. This is consistent with a high geothermal gradient $\left(\sim 40^{\circ} / \mathrm{km}\right)$ and high Tertiary sedimentation rate $(\sim 80 \mathrm{~m} / \mathrm{m} . \mathrm{y}$.) giving a short effective heating time at this site.

With the reservations already presented in the report, the mean reflectance values both above and below the 100-m.y. Cretaceous-Miocene unconformity fall on a single straight line (Figure 1). This indicates that there is no dramatic increase in maturity across the unconformity, and hence that the Hauterivian sediments under the unconformity have never been exposed to significantly higher temperatures than present today. Assuming a constant geothermal gradient, this indicates that at Site 397 less than 1300 meters of sediment were deposited and erroded during the 100 m.y. between Hauterivian and lower Miocene times.

\section{Provenance of the Organic Matter}

The organic component of the continental rise sediments of DSDP Site 397 appears to be dominated by a terrestrial (higher plant) input for both Tertiary and Lower Cretaceous sediments.

Lithostratigraphic Units 1, 2, and 3: These units contained low organic carbon contents $(\sim 0.5 \% \mathrm{C}$; Site Report, this volume). The microscopic study of the kerogen concentrates from Units 1, 2, and 3 showed them to contain predominantly higher plant particles such as pollen, cuticle, and vitrinite (Table 1). A high terrestrial component was confirmed by the $n$-alkane distributions (Figure 4A, B) which showed a dominance of alkanes in the $C_{25}$ to $C_{31}$ range, with a high odd carbon 

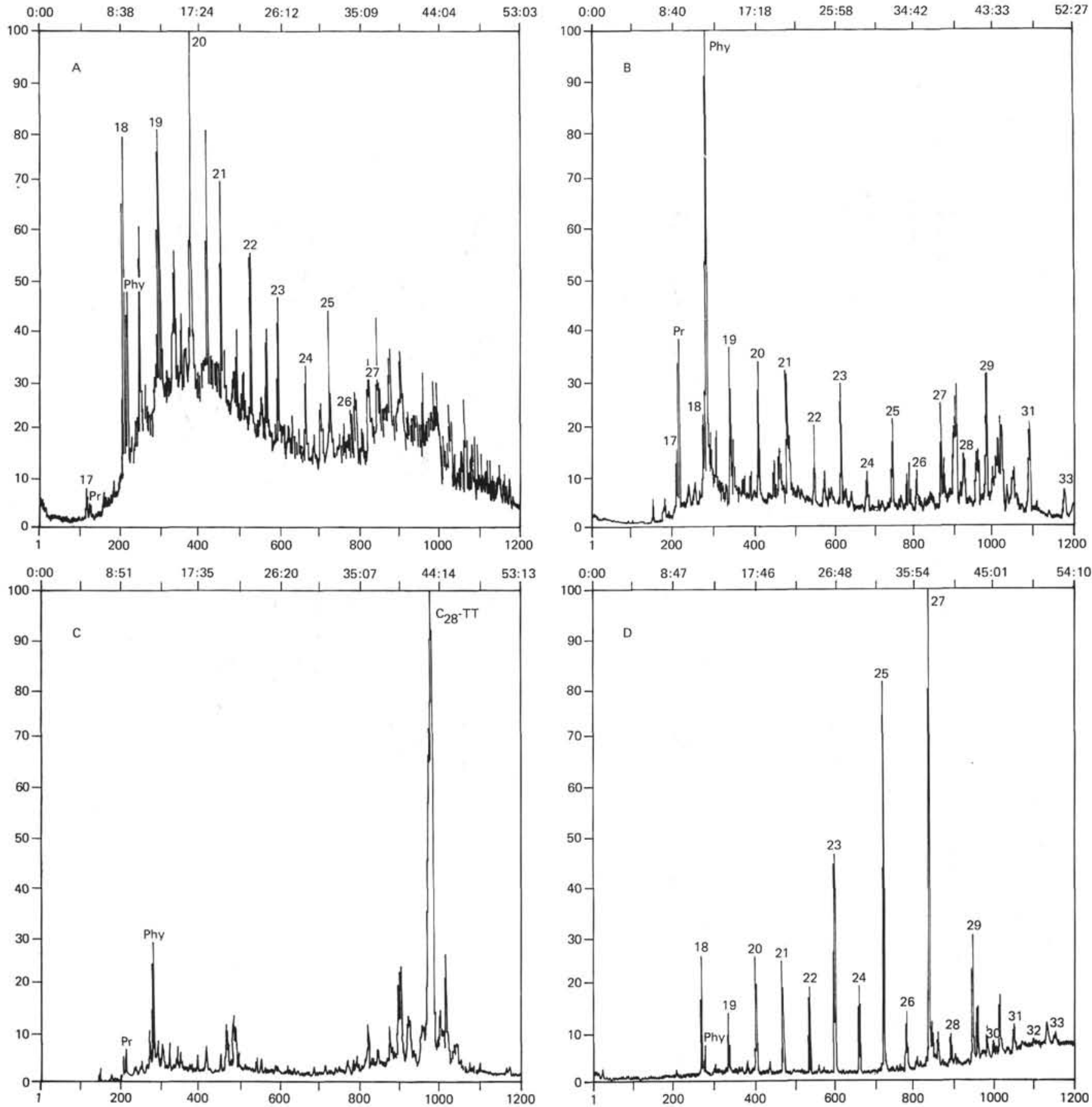

Figure 6. Reconstructed total ion current chromatograms from mass spectrometric analysis of selected samples, $(A)$ 397-87-2 (828 m); (B) 397-AJ-26-4 (1180 m); (C) 397A-28-2 (1241 m); and (D) 397A-52-3 (1450 m). Numbers indicate $\mathrm{n}$-alkanes; $\mathrm{Pr}=$ pristane, $\mathrm{Phy}=$ phytane, $T \mathrm{~T}=$ triterpane.

number preference (Table 3 ). These results require some discussion since, paradoxically, these units consist of hemipelagic sediments where the major sedimentary component is the carbonate or silica skeletons of microfossils and nannofossils.

It has been suggested from studies of both recent and ancient sediments (Gaskell et al., 1975; Simoneit, 1978a) that aeolian transport may be responsible for introducing quantities of terrestrial organic matter into deep water Atlantic sediments off the western coast of Africa. Both these studies reported $n$-alkane and fatty acid distributions similar to those exhibited by higher plants. The possibility of the eolian mechanism has been confirmed by Simoneit and Eglinton (1977), who found higher plant $n$-alkane and $n$-fatty acid distributions in eolian dust currently falling over this area of the eastern Atlantic. However, $n$-alkane distributions can be misleading since it appears that a minor plant 

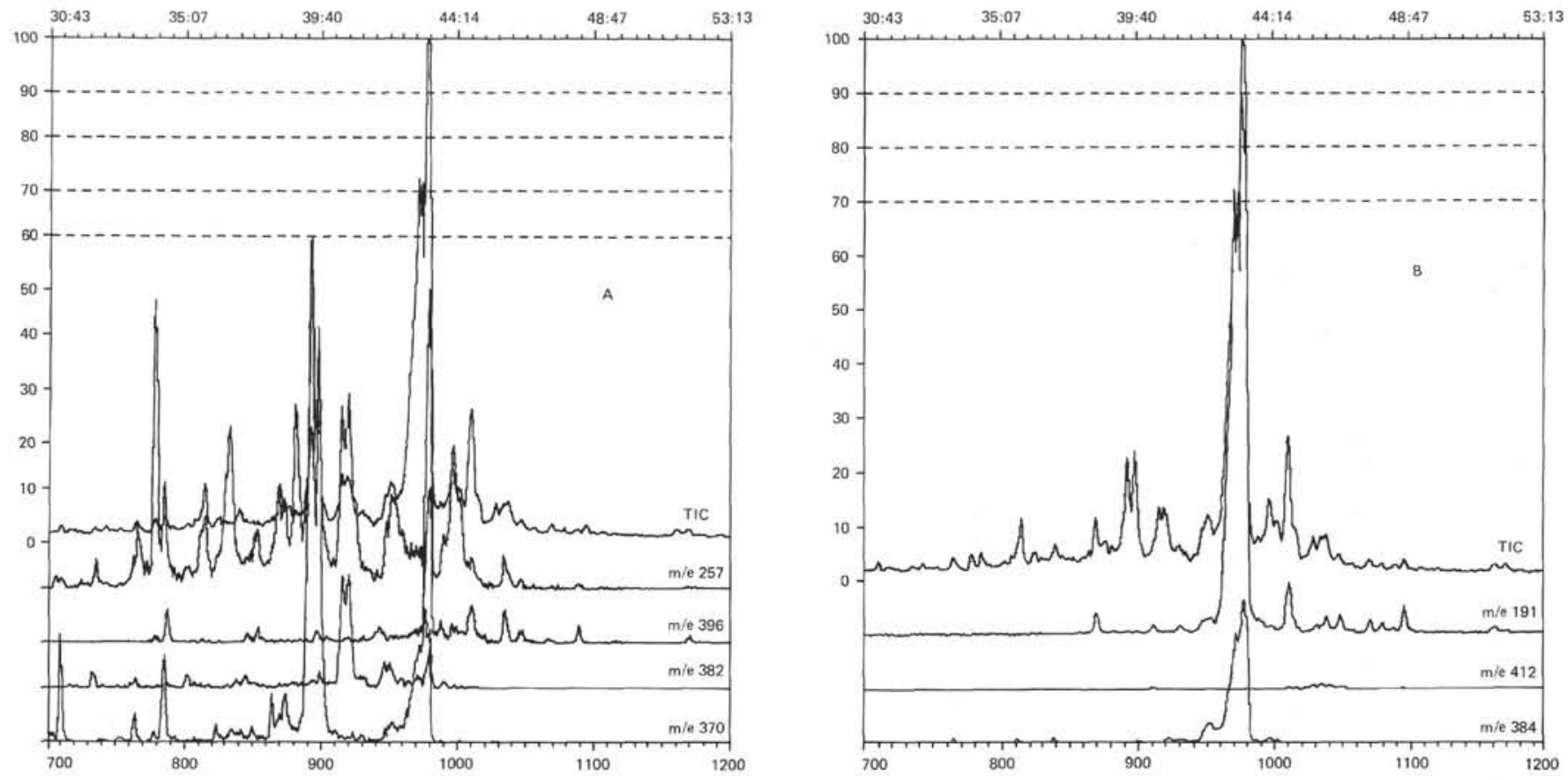

Figure 7. Sample 397A-28-2 (1241 m). (A) Mass chromatogram (scans 700 to 1200$)$ of m/e 370 ( $C_{27}-s t e r e n e s$ or pen tacyclic $C_{27}$-triterpanes), m/e 382 ( $C_{28}$-steradienes or pentacyclic $C_{28}$-triterpenes), m/e 396 ( $C_{28}$-steradiences or pentacyclic $C_{29}$-triterpenes), and $\mathrm{m} / \mathrm{e} 257$ (key fragment of unsaturated steriod hydrocarbons). (B) Mass chromatogram (scans 700 to 1200) of m/e 384 (pentacyclic $C_{28}$-triterpanes or $C_{28}$-sterenes), $m / e 412$ (pentacyclic $C_{30}$-triterpanes or $C_{30}$-sterenes), and $\mathrm{m} / \mathrm{e} 191$ (key fragment of triterpenoid hydrocarbons). TIC = total ion current.

cuticle content can produce a major $\mathrm{C}_{25}$ to $\mathrm{C}_{31}$ odd/ even dominant peak, while a major algal input is needed to give a $\mathrm{C}_{15}$ to $\mathrm{C}_{17}$ peak.

The terrestrial input at Site 397 is confirmed by the clay mineral analysis (Chamley, this volume), which shows a considerable fraction ( $25 \%$ of silicates) to be illite and kaolinite of presumed terrestrial derivation.

The relative proportions of terrestrial and marine organic matter are still not explained. Upwelling and high planktonic bioproductivity of the western coast of Africa is evidenced in the Neogene at Site 397 by the rapid sedimentation ( $80 \mathrm{~m} / \mathrm{m}$.y. of foraminiferal and nannofossil oozes), but the organic matter of the zooplankton and phytoplankton does not appear to survive to be incorporated into the sediment. Menzel (1974) has noted that particulate organic matter in the ocean waters is high in the zone of planktonic productivity, but falls to a steady and low level by 200 to 400 meters depth. Below this depth, absolute values are not affected by surface bioproductivity. He also notes that the majority of what sinks below 400 meters is contained in fecal pellets. From the evidence at Site 397, it appears that terrestrial organic matter can better survive this passage though the ocean waters, and becomes the dominant organic component in the sediments.

Lithostratigraphic Unit 4: Based on the results of microscopy (Table 1) and $n$-alkane distributions (Figures 4 and 6 ), the allochthonous Miocene sediments contain organic matter of a mixed aquatic and terrestrial origin. The sediments are predominantly clastic clays, silts, and sands, which from their microfaunas appear to have been derived (by slumping or turbid flow) from an outer-shelf or upper-slope environment (Site Report, this volume). The dominance of phytane over pristane found in the Unit 4 samples indicates, at low maturity levels, a reducing environment (Cornford and Douglas, in press), but they are interlayered with the highly bioturbated Facies 5 chalks (Site Report, this volume). Bioturbation is taken to indicate an oxidizing environment. This contradiction is resolved by supposing that the allochthonous lithologies of Unit 4 were initially deposited under reducing conditions on the shelf edge, then arrived in the oxidizing deep water rise environment by mass transport. Since reducing conditions on the shelf edge are generally associated with the oxygen minimum (Schlanger and Jenkins, 1976), this provides indirect evidence for the presence of an oxygen-minimum zone in shallow depth for the Miocene of the North Atlantic.

Lithostratigraphic Unit 5: In common with the majority of DSDP samples taken from Cretaceous sediments of the Atlantic, the Site 397 Hauterivian sediments contained organic matter of higher plant origin (Table 2).

A puzzling outcome of the investigation was the presence of unsaturated cyclic hydrocarbons even in the Cretaceous sample at 1450 meters $\left(65^{\circ} \mathrm{C}\right.$ projected). Carbon-carbon double bonds are unstable under geologic conditions and are generally lost in the early stages of burial. Investigations of sterol diagenesis in continental sediments show that most of the sterols 

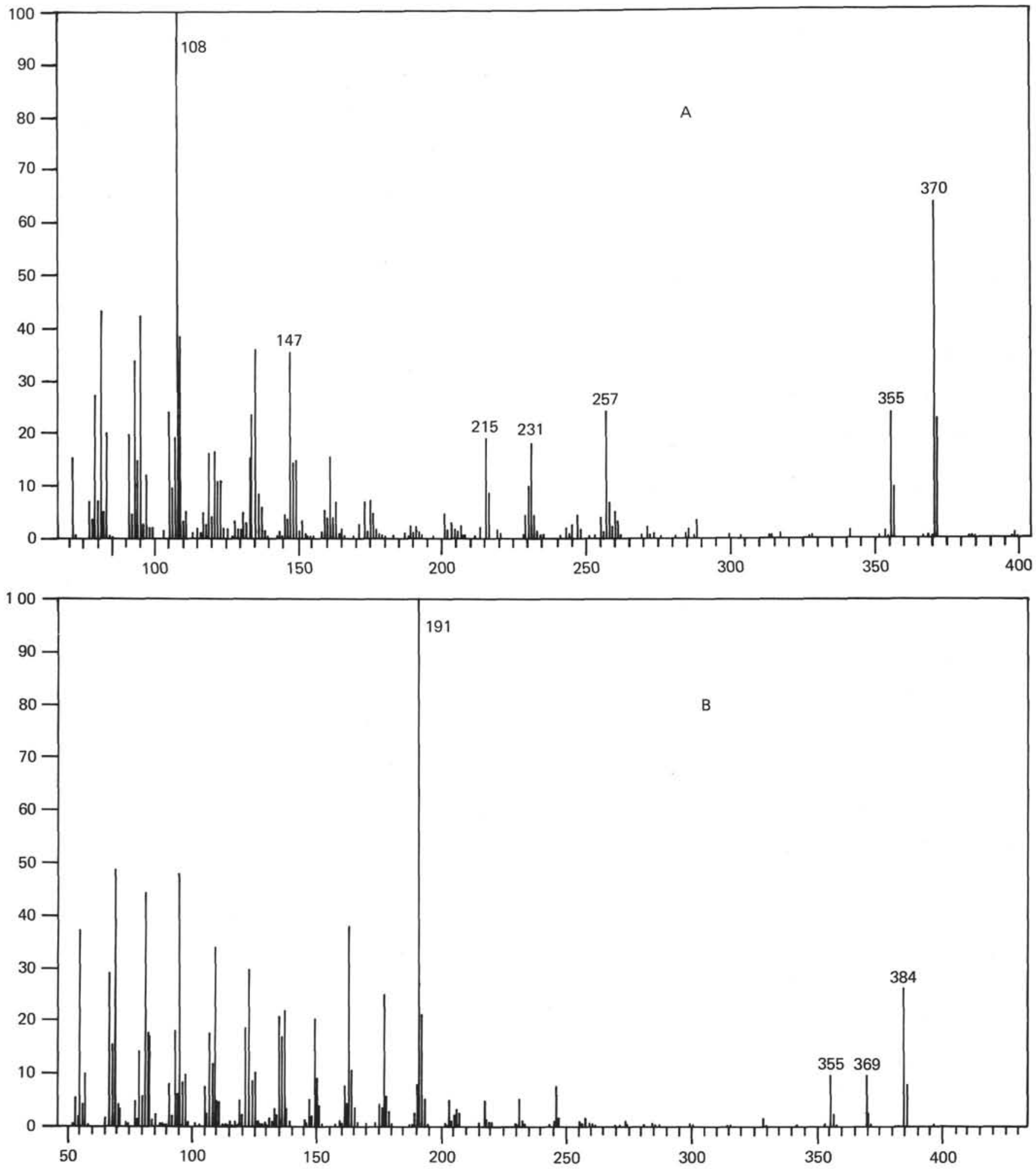

Figure 8. Sample 397A-28 (1241 m). (A) Mass spectrum of scan 892 ( $\triangle^{4}$-cholestene); (B) Mass spectrum of scan 975 $\left(C_{28}\right.$-triterpane). For both spectra, background subtraction was performed.

are hydrogenated to stanols in the uppermost sediment layers (Gaskell and Eglinton, 1973, 1974; Nishimura and Koyama, 1976, 1977). No reports are known to the authors of the occurrence of large amounts of unsaturated steroid and triterpenoid hydrocarbons in continental sediments buried to depth of $1 \mathrm{~km}$ or more. Unsatu- rated cyclic compounds are already known from less deeply buried deep-sea sediments (Simoneit, $1978 \mathrm{a}, \mathrm{b}$ ).

Since the unsaturated cyclic compounds are found at Site 397 in samples containing both terrestrial and marine matter, an exotic origin is not indicated. An alternative explanation is that the environment of deposi- 
tion contributes to their preservation. It is reasonable to presume that deposition, at least from Miocene times on, has occurred in deep $(3000 \mathrm{~m})$, cold $\left(3^{\circ} \mathrm{C}\right)$, and oxidizing waters. In the allochthonous sediments, bioturbation has been minimal. Some combination of these factors may be responsible for the preservation of the unsaturates. Further investigations will reveal whether their presence is a common factor in deep-sea sediments.

\section{Hydrocarbon Source Rocks}

Of the five lithostratigraphic units investigated at Site 397 , only one (Unit 4), can be rated as having a reasonable source rock potential. In this unit, appreciable liquid hydrocarbons might be expected from the liptinite component of the organic matter (Table 1). Unit 4, some 500 meters thick, also contains porous sands which could act as potential paths for migration and possibly accumulation. But as discussed in earlier in this report, the sediments are immature. Given the vitrinite reflectance gradient at Site 397 (Figure 1), burial to at least 1500 to 2000 meters would be required to generate hydrocarbon in this area. With this burial, Unit 4 could act as a source rock for liquid hydrocarbons.

The continental rise system of the world constitutes a huge volume of sediments. If they contain good hydrocarbon source material, i.e., aquatic (planktonic) organic matter, they would be of great interest as petroleum source rocks. Evidence from DSDP Site 397 indicates that terrestrial matter dominates in the autochthonous sediments even in an area of upwelling and high planktonic bioproductivity. But Site 397 investigations also show that mass transport of sediments from the continental shelf edge provides a mechanism for bringing higher quality hydrocarbon source material into the continental rise.

\section{ACKNOWLEDGMENTS}

We thank Dr. M. Radke and Dr. R. Schaefer for carrying out extraction and gas chromatography, respectively; and Miss I. Jacobs, Mr. W. Benders, and Mr. F.-J. Keller for technical assistance. Further, we gratefully acknowledge corrections and suggestions made by Dr. Hagemann and Dr. Hollerbach of the Technische Hochschule, Aachen, and thank them for reviewing the manuscript.

\section{REFERENCES}

Cornford, C. and Douglas, A. G., in press. Some results from the analysis of hydrocarbons and fatty acids of Jurassic limestone/shale sequences of the west European province, Advances in organic geochemistry.
Demaison, G. T., 1975. Relationship of coal rank to paleotemperatures in sedimentary rocks. In Alpern, B. (Ed.), Colloque International, Pétrographie de la Matiere Organique des Sediments, Relations avec la Paleotemperature et le Potentiel Petrolier: Paris (C.N.R.S.), p. 217.

Dow, W. G., 1977. Kerogen studies and geological interpretations, Journal of Geochemical Exploration, v. 7, p. 79.

Gaskell, S. J. and Eglinton, G., 1973. Rapid hydrogenation of sterols in a contemporary lacustrine sediments, Nature, v. 254 , p. 209.

1974. Short-term diagenesis of sterols. In Tissot, B. and Bienner, F. (Eds.) Advances in organic geochemistry: Paris (Technip), p. 963.

Gaskell, S. J., Morris, R. J., Eglinton, G., and Calvert, S. E., 1975. The geochemistry of a recent marine sediment off northwest Africa. An Assessment of source of input and early diagenesis, Deep-Sea Research, v. 22, p. 777.

Menzel, D. W., 1974. Primary productivity, dissolved and particulate organic matter, and the sites of oxidation of organic matter. In Goldberg, E. (Ed.), The sea: New York (Interscience), v. 18.

Nishimura, M. and Koyama, T., 1976. Stenols and stanols in lake sediments and diatoms, Chemical Geology, v. 17, p. 229.

$\longrightarrow$ 1977. The occurrence of stanols in various living organisms and the behavior of sterols in contemporary sediments, Geochimica et Cosmochimica Acta, v. 41, p. 379.

Raynauld, J.-F. and Robert, P., 1976. Les méthodes d'étude optique de la matiére organique, Bulletin du Centre de Recherches Pau-SNPA, v. 10, p. 109.

Schlanger, S. O. and Jenkins, H. C., 1976. Cretaceous oceanic events: causes and consequences, Geologie en mijnbouw, v. 55 , p. 179.

Simoneit, B. R. T., 1978a. Leg 41 sediment lipids - Search for eolian organic matter in recent samples and examination of a black shale. In Lancelot, Y., Seibold, E., et al., Initial Reports of the Deep Sea Drilling Project, v. 41: Washington (U.S. Government Printing Office, p. 855-858. , 1978b. Organic geochemistry of terrigenous muds and various shales from the Black Sea, DSDP Leg 42B. In Ross, D., Neprochnov, Y., et al., Initial Reports of the Deep Sea Drilling Project, v. 42, Part 2: Washington (U.S. Government Printing Office), p. 749-754.

Simoneit, B. R. T. and Eglinton, G., 1977. Organic matter in eolian dust and its input to marine sediments. In Campos, R. and Goni, J. (Eds.), Advances in organic geochemistry: Madrid (Enadimsa), p. 415.

Stach, E. Mackowsky, M.-Th., Teichmuller, M., Taylor, G. H., Chandra, D., and Teichmüller, R., 1975. Stach's textbook of coal petrology: Berlin (Gebrüder-Bornsträger).

Teichmüller, M. and Wolf, M., 1977. Application of fluorescence microscopy in coal petrology and oil exploration. Journal of Microscopy, v. 109, p. 49.

Wyllie, S. G. and Djerassi, C., 1968. Mass spectrometry in structural and stereochemical problems. CXLVI. Mass spectrometric fragmentation of sterols with unsaturated side chains, Journal of Organic Chemistry, v. 33, p. 305. 